\title{
EFFECT OF THE USE OF COOKING PRODUCT OF THE STEM CONTENT OF GEBANG (CORYPHA UTAN LAMK.) PLANT WITH UREA ON THE GROWTH OF BALI CATTLE
}

\author{
Lazarus Edwin J.L. ${ }^{1,2 \star}$, Soetanto H. ${ }^{1}$, Marjuki ${ }^{1}$, Retnowati R. ${ }^{3}$ \\ ${ }^{1}$ Faculty of Animal Husbandry, University of Brawijaya, Malang, Indonesia \\ ${ }^{2}$ Faculty of Animal Husbandry, University of Nusa Cendana, Kupang, Indonesia \\ ${ }^{3}$ Faculty of Mathematics and Natural Sciences, University of Brawijaya, Malang, Indonesia \\ *E-mail: edwinjlazarus@gmail.com
}

\begin{abstract}
The purpose of this study was to evaluate the impact of the use of slow release urea products from the cooking result of gebang starch (putak) with urea in concentrate feed as feed supplements on the growth of Bali cattle. Sixteen male Bali cows (body weight of $192.71 \pm 19.17 \mathrm{~kg}$ ) used in a completely randomized design $4 \times 4$. Livestock were randomly allocated to get one of the treatments of the use of purea (cooking of putak meal with $6 \%$ urea) in concentrate feed, namely $\mathrm{T}_{0}$ : putak meal mixed with urea (the amount of putak meal $60 \%$ in concentrate, the amount of urea $3 \%$ from putak meal), $\mathrm{T}_{1}$ : purea $20 \%, \mathrm{~T}_{2}$ : purea $40 \%$, $\mathrm{T}_{3}$ : purea $60 \%$. King grass is used as basal feed in comparison with a 60: 40 concentrate. The research results showed the consumption of dry matter, organic matter, crude protein, crude fiber and total digestible nutrients did not differ due to the use of purea, but the digestibility of dry matter, organic matter, crude protein and crude fiber, weight gain, and efficiency of feed use differ among the treatments. The use of purea to $40 \%$ level in concentrate feed is better in increasing the growth compared to the use of urea mixture with putak meal without cooking. The use of purea does not cause cattle to experience health problems or poisoning.
\end{abstract}

\section{KEY WORDS}

Efficiency of feed use, economic value, synchronization, slow release urea.

Bali cattle is reliable livestock commodity on dry land with dry climate in the province of East Nusa Tenggara, Indonesia; but its growth is limited because it is not supported by the availability of sufficient feed in terms of quality and quantity. In the dry season, the dominant feed consumed by Bali cows is natural grass with very low quality (CP 2-4\%) and cell wall content can reach $80 \%$ (Fattah, 1998). This condition is very unlikely to support the fulfillment of the basic needs of ruminant cattle (Chanjula and Ngampongsai, 2008), even livestock can experience $20 \%$ loss of life weight due to low feed consumption (Bamualim, 1991). Wirdahayati and Bamualim (1990) reported that during the dry season calves less than one year old lost weight at $0.15-0.22 \mathrm{~kg} / \mathrm{head} /$ day and young steers $0.34-0.35 \mathrm{~kg} / \mathrm{head} / \mathrm{day}$ and late in the dry season mature bulls and cows might experience even more severe weight loss $(0.42-0.52 \mathrm{~kg} / \mathrm{head} / \mathrm{day})$.

The use of NPN, such as urea as feed supplement can increase the consumption and digestibility of feed as well as the performance of livestock that consume low-quality forage and most importantly it costs less than using natural protein. Urea can also be used as an effective alternative to replace soybean meal based supplements and produces more $\mathrm{N}$ than pure protein sources per unit of N (Mentz et al., 2015; Gardinal et al., 2016). Cattle that consume high amounts of forage will generally meet their nitrogen needs with urea supplementation (Gardinal et al., 2016). Although many studies have shown that the performance of urea supplements is usually lower than the natural food, with the increasing price of feed protein, urea has become a cost-effective protein substitute (Cui et al., 2015). However, the use of urea in cattle feed is less efficient because the speed of dissolution in the rumen and the use of ammonia becomes less perfect by rumen microbes, with the occured of accumulation and absorption of ammonia so that a lot of ammonia is excreted in urine (Highstreet et al.,2010). 
The use of the the stem contents (pith) of gebang (Corypha utan Lamk.) Plant as a source of carbohydrates (starch) which cooked with urea can increase synchronization of the release of ammonia and energy to produce microbial protein synthesis. According to Jittakot (1999), during the cooking process at high temperature and pressure, starch will mix with urea and gelatinized, forming a homogeneous mass and will decomposed slowly in the rumen, releasing urea gradually and hence the ammonia supply and energy occur simultaneously for the synthesis of microbial protein. Rodrigues (2003) states, if there is no synchronization between ammonia and carbohydrates in the rumen there can be a loss of nitrogen up to $40 \%$. In general, the product developed is called slow release urea (SRU), and has been studied as an alternative to reduce the high urea solubility in the rumen, high excretion through the kidneys and ammonia poisoning from urea. (Wanapat, 2000; Goncalves et al., 2015). Similarly, Inostroza et al. (2009) suggested that slow release urea products can be useful in reducing poisoning, increasing the acceptability of supplements and the use of urea as well as improving ruminant performance. Galo et al. (2003) and Xin et al. (2010) reported that slow release urea in dairy cattle feed could increase the total consumption and digestibility of dry matter and crude protein of feed. Likewise SicilianoJones and Downer (2005) states that slow release urea can replace a number of soybean meal proteins to meet the needs of easily degraded protein in the rumen and lead to additional space in the rumen which available for the provision of dry matter of forage and grains. Even according to Calomeni et al. (2015) slow-release urea from polymer coating, hydrolyzed into ammonia slower than urea and can be used more efficiently by rumen microorganisms and improves livestock production performance. Bali cattle is very well adapted to the poor nutritional conditions of the environment so that with the supplementation of feed using materials available around the environment is expected could increase the growth.

The purpose of this study was to evaluate the impact of the use of slow-release urea products from the cooking of gebang starch with urea as a feed supplement on the growth of Bali cattle.

\section{MATERIALS AND METHODS OF RESEARCH}

The study was conducted in a cattle shed owned by the Regional Technical Implementation Unit/Unit Pelaksana Teknis Daerah (UPTD) of Cattle Farming from The Animal Husbandry Office of the Province of East Nusa Tenggara, in Lili, Kupang Regency.

A total of sixteen male Bali cows aged 1.5-2 years with a body weight of $192.71 \pm$ $19,17 \mathrm{~kg}$ used as experimental animal. Feed is arranged in the ratio of forage: concentrate (60: 40). The forage used is king grass (Penisetum purpurephoides), while the concentrate consists of: fish meal, ground corn, rice bran, palm kernel cake, coconut cake and mineral mixture, flour of gebang stem content known as "putak", urea as well as the cooking product of the contents of the gebang stem with urea which is named "purea". Purea is made by mixing urea with putak meal (the amount of urea is $6 \%$ of the total Dry Matter of putak meal) then put in a HDPE heat resistant plastic bag with brand BELL ISO-9000 No. 005 / 223-1998 and cooked in an autoclave at $135^{\circ} \mathrm{C}$ with a pressure of $186 \mathrm{kPa}$, cooking time 60 minutes. The moisture content of material $60 \%$. Feed compiled iso protein to meet the needs of $13 \%$ crude protein (NRC, 2000). All feed ingredients are analyzed before the field research conducted. Drinking water is given ad libitum.

This study used a Completely Randomized Design with 4 treatments that were repeated 4 times. The treatment applied was the provision of concentrate as supplement feed with purea level in concentrate feed as follows, $T_{0}=$ putak meal mixed with urea (the amount of putak meal $60 \%$ from the concentrate, the amount of urea $3 \%$ from putak meal) as control, $\mathrm{T}_{1}=$ purea $20 \%$ in concentrate feed, $\mathrm{T}_{2}=$ purea $40 \%$ in the concentrate feed, and $\mathrm{T}_{3}$ $=$ purea $60 \%$ in the concentrate feed.

Measurement of feed consumption is done every day for 60 days by weighing the feed provision and the rest every day. The rest of the forage collected 100 grams per day during the study. Cow feces were collected in the last week of observation. At the end of the 
observation time the feed and faecal samples composited and taken 100 grams to be analyzed for the content of dry matter (DM), organic matter (OM), crude protein (CP), and crude fiber (CF) according to the proximate analysis method (AOAC, 2000).

Response variables measured included consumption and digestibility of dry matter (DM), organic matter (OM), crude protein (CP), crude fiber (CF), body weight gain, and feed efficiency. Digestion of feed nutrients, measured the amount of feed nutrients consumed minus the nutrients released through feces divided by the amount of nutrients consumed multiplied by $100 \%$. Body weight gain, obtained by dividing the final body weight of the cattle minus the initial body weight divided by the time of observation. Efficiency of feed use, measured the amount of feed consumed for each body weight gain.

All research data were tabulated and then analyzed statistically using analysis of variance according to the experimental design used and followed by Duncan's multiple range test using the general linear procedure (GLM) of Statistical Analysis System (SAS, 2000). All data in the table are presented as a mean value and standard deviation (mean value \pm standard deviation).

\section{RESULTS AND DISCUSSION}

The composition of the feed ingredients and the chemical composition of treatment feed are shown in Table 1. The composition of the research feed ingredients varies according to the increase in the percentage of purea in the feed. Nutrient composition of feed from each treatment in the same range to support the fulfillment of needs for cattle growth.

Table 1 - The composition of the ingredients of the research ration

\begin{tabular}{|c|c|c|c|c|}
\hline $\mathrm{n} / \mathrm{n}$ & $\mathrm{T}_{0}$ & $\mathrm{~T}_{1}$ & $\mathrm{~T}_{2}$ & $T_{3}$ \\
\hline \multicolumn{5}{|l|}{ Feed ingredients, } \\
\hline King grass & 60 & 60 & 60 & 60 \\
\hline Fish meal & 2.5 & 5.6 & 4.5 & 2.5 \\
\hline Palm kernel cake & 0.12 & 6.5 & 4.5 & 6.25 \\
\hline Coconut meal & 12.46 & 3.5 & 5.5 & 6.5 \\
\hline Rice bran & 0.1 & 6.4 & 7.5 & 0.5 \\
\hline ground corn & 0.1 & 10 & 2.0 & 0.25 \\
\hline Putak & 24 & 0 & 0 & 0 \\
\hline Urea & 0.72 & 0 & 0 & 0 \\
\hline Purea & 0 & 8 & 16 & 24 \\
\hline Total & 100 & 100 & 100 & 100 \\
\hline \multicolumn{5}{|l|}{ Chemical Composition, \% } \\
\hline Dry matter & 44.20 & 44.73 & 43.56 & 42.05 \\
\hline Organic matter & 87.96 & 87.75 & 87.98 & 88.70 \\
\hline Crude protein & 13.09 & 13.22 & 13.49 & 13.30 \\
\hline Crude fiber & 22.60 & 24.17 & 24.30 & 23.58 \\
\hline Crude fat & 5.42 & 4.52 & 4.67 & 4.09 \\
\hline BETN & 43.70 & 39.27 & 38.74 & 40.37 \\
\hline TDN & 61.27 & 60.94 & 61.09 & 61.31 \\
\hline
\end{tabular}

The data in Table 2 shows the response of Bali cattle on the use of purea in concentrate rations showed no effect $(P>0.05)$ on feed consumption (DM, OM, CP and CF) of Bali cattle. The use of purea as a supplement in Bali cattle feed is no different from the use of urea-putak mixture without cooking. The use of purea, which contains $6 \%$ urea can be tolerated by Bali cattle with the same consumption as 3\% urea mixed with putak without cooking. According to Golombeski et al. (2006), the addition of slow release urea products causes $\mathrm{N}$ to be released more slowly in the rumen, retains slow release properties for a long time of provision and provides the same performance as urea supplements without the potentially harmful effects associated with urea. The use of slow release urea in feed can maintain feed consumption in accordance with the level of production achieved with rations containing urea in beef cattle (Sinclair et al., 2001). The use of purea up to the level of $40 \%$ in concentrate feed increases consumption and the use above that level decreases 
consumption. The results of this study are the same as those reported by Paengkoum and Bunnakit (2009) in Thai and Brahman crossbred cattle which given a gelatinization supplement of a mixture of cassava pulp with urea as a substitute for soybean meal in concentrate feed, get an increase in feed consumption to the level of use of $40 \%$ but statistically not different. The research results of Alves et al. (2014a) found that the substitution of urea with slow release urea did not change the consumption of sheep rations.

According to Goncalves et al. (2015) the use of slow release urea up to the level of $40 \%$ in concentrate feed in a total mixture of rations with low-quality forage can maintain feed consumption in accordance with the level of production achieved for beef cattle in rations containing urea. Mastika (2003) in a study on Bali cattle which given concentrate on a feedlotting system for 112 days obtained feed consumption of $78.83 \mathrm{~g} / \mathrm{kg} \mathrm{BW}^{0,75}-106.25$ $\mathrm{g} / \mathrm{kg} \mathrm{BW} \mathrm{B}^{0,75}$. The high feed consumption in the study compared to this study, because the research time is longer than the study conducted (60 days). The use of urea with putak without cooking $\left(T_{0}\right)$ as a supplement results in low feed consumption. Xin et al. (2010) reported that the consumption of cow dry ingredients which given urea coated with polyurethane was the same as those given soybean meal. Consumption of OM, CP and CF increases with increasing levels of purea use on the level of $40 \%$ in concentrate feed.

The drymatter digestibility of the feed of Bali cattle that got $40 \%$ purea was significantly higher $(P<0.05)$ than those that got $60 \%$ purea and those which got the urea-putak mixture without cooking, whereas in cows that received $20 \%$ purea there was no difference. The same phenomenon occurs in Organic matter digestibility. $T_{2}$ treatment was higher than $T_{3}$ and $T_{0}$ but with $T_{1}$ was not different in the digestibility of DM and OM. CP $T_{2}$ digestibility $\left(T_{2}\right)$ is not different from $T_{0}$. Digestibility of CF did not differ among treatments. Increase in feed consumption causes increase in digestion, causing rumen emptying faster. The results of this study are the same as reported by Geron et al. (2016) that the use of $1.2 \%$ slow release urea in sheep ration did not change the consumption of nutrients and rumen parameters.

Table 2 - The response of research cattle on the response variable

\begin{tabular}{|c|c|c|c|c|c|}
\hline $\mathrm{n} / \mathrm{n}$ & $\mathrm{T}_{0}$ & $\mathrm{~T}_{1}$ & $\mathrm{~T}_{2}$ & $\mathrm{~T}_{3}$ & SEM \\
\hline \multicolumn{6}{|c|}{ Feed consumption, $\mathrm{g} / \mathrm{kg} \mathrm{BW}^{0, / 5}$} \\
\hline DM of King grass & $45.67 \pm 3.60$ & $48.54 \pm 2.06$ & $50.61 \pm 1.08$ & $46.76 \pm 4,78$ & 1.08 \\
\hline DM of Concentrate & $32.36 \pm 2.94$ & $31.53 \pm 2.11$ & $30.51 \pm 1.05$ & $31.15 \pm 3.04$ & 0.38 \\
\hline Total DM & $78.03 \pm 6.10$ & $80.07 \pm 3.79$ & $81.07 \pm 1.58$ & $77.92 \pm 7.27$ & 0.78 \\
\hline DM of King grass & $39.09 \pm 3.08$ & $41.55 \pm 1.76$ & $43.28 \pm 0,89$ & $40.03 \pm 4,09$ & 0.92 \\
\hline OM of Concentrate & $30.16 \pm 2.74$ & $28.69 \pm 1.92$ & $27.92 \pm 0.96$ & $29.08 \pm 2.84$ & 0.47 \\
\hline Total OM & $69.25 \pm 5.42$ & $70.24 \pm 3.35$ & $71.20 \pm 1.40$ & $69.11 \pm 6.43$ & 0.49 \\
\hline CP of King grass & $4.61 \pm 0.36$ & $4.90 \pm 0.21$ & $5.11 \pm 0.11$ & $4.72 \pm 0.48$ & 0.11 \\
\hline $\mathrm{CP}$ of Concentrate & $7.07 \pm 0.64$ & $6.96 \pm 0.47$ & $6.90 \pm 0.24$ & $6.89 \pm 0.67$ & 0.04 \\
\hline Total CP & $11.68 \pm 50.94$ & $11.86 \pm 0.94$ & $12.01 \pm 0.27$ & $11.61 \pm 1.07$ & 0.09 \\
\hline CF of King grass & $15.09 \pm 1.19$ & $16.04 \pm 0.68$ & $16.70 \pm 0.34$ & $15.45 \pm 1.58$ & 0.35 \\
\hline CF of Concentrate & $2.31 \pm 0.21$ & $3.44 \pm 0.23$ & $3.43 \pm 0.12$ & $2.94 \pm 0.29$ & 0.27 \\
\hline Total CF & $17.40 \pm 1.35^{\mathrm{b}}$ & $19.48 \pm 0.85^{a}$ & $20.14 \pm 0.38^{a}$ & $18.39 \pm 1.0^{\mathrm{ab}}$ & 0.60 \\
\hline \multicolumn{6}{|l|}{ Feed digestibility, \% } \\
\hline Dry Matter & $60.53 \pm 5.10^{b}$ & $62.73 \pm 3,13^{\mathrm{ab}}$ & $66.79 \pm 0.34^{\mathrm{a}}$ & $59.66 \pm 1.34^{b}$ & 1.59 \\
\hline Organic matter & $62.05 \pm 4.91^{b}$ & $64.17 \pm 3.04^{\text {ab }}$ & $68.12 \pm 0.39^{\mathrm{a}}$ & $61.35 \pm 1.21^{\mathrm{b}}$ & 1.52 \\
\hline Crude protein & $79.84 \pm 2.25^{\mathrm{ab}}$ & $78.62 \pm 0.94^{\mathrm{b}}$ & $82.32 \pm 0.52^{a}$ & $75.43 \pm 2.92^{\mathrm{C}}$ & 1.43 \\
\hline Crude fiber & $27.35 \pm 15.84^{b}$ & $38.75 \pm 8.91^{\mathrm{a}}$ & $42.89 \pm 5.62^{\mathrm{a}}$ & $25.23 \pm 4.45^{\mathrm{ab}}$ & 4.30 \\
\hline Initial body weight, kg & $193.40 \pm 25.12$ & $190.55 \pm 19.14$ & $192.55 \pm 12.47$ & $194.33 \pm 28.82$ & 0.81 \\
\hline Final body weight, kg & $207.63 \pm 27.35$ & $211.70 \pm 16.04$ & $224.28 \pm 8.40$ & $206.33 \pm 28.77$ & 4.09 \\
\hline Body Weight Gain, kg & $0.24 \pm 0.16^{\mathrm{b}}$ & $0.36 \pm 0.13^{\mathrm{ab}}$ & $0.53 \pm 0.14^{\mathrm{a}}$ & $0.24 \pm 0.05^{\mathrm{b}}$ & 0.07 \\
\hline Efficiency of feed use & $0.06 \pm 0.04^{b}$ & $0.08 \pm 0.03^{\mathrm{ab}}$ & $0.12 \pm 0.03^{\mathrm{a}}$ & $0.06 \pm 0.01^{b}$ & 0.01 \\
\hline
\end{tabular}

${ }^{a b c}$ Averages in the same row with the different superscript differences at $P<0,05$; SEM = Standart Error of the Mean.

Feed digestibility (DM, OM, CP and CF) is in line with feed consumption where Bali cows which given $40 \%$ purea in concentrate feed produce higher digestibility among the treatments. Contribution of purea as a slow release urea product in feed can meet the needs of microbes that characterized by increase in nutrient digestibility and increase in rate of passing feed in the rumen. The higher the digestibility value of feed in the provision of purea, 
the higher the nutrients absorbed by livestock for their growth needs. Geron et al. (2016) concluded that the use of $0.66 \%$ slow release urea in sheep feed produces the best digestibility of crude protein. Consumption of digested nutrients among the treatments did not differ $(P>0.05)$ which indicated the use of purea had no effect on energy consumption; however there is a tendency for an increase in consumption to a level of $40 \%$ purea compared to when using an urea-putak mixture without cooking. Almost the same results as reported by Castaneda-Serrano et al. (2013) that the use of slow release urea replaces conventional urea in beef cattle rations does not change the consumption and total digestibility of nutrients.

Body weight gain of Bali cattle that received purea in concentrate feed showed a significant difference $(P<0.05)$ while the efficiency of feed use was not significant $(P>0.05)$ its effect. Body weight gain of Bali cattle that received a mixture of urea-putak without cooking experienced a ADG of $0.24 \mathrm{~kg} / \mathrm{h} / \mathrm{d}\left(\mathrm{T}_{0}\right)$ and increase to $0.36 \mathrm{~kg} / \mathrm{h} / \mathrm{d}$ on the provision of purea $20 \%\left(T_{1}\right)$ in concentrate feed and $0.52 \mathrm{~kg} / \mathrm{h} / \mathrm{d}$ on the provision of purea $40 \%\left(T_{2}\right)$. In the provision of $60 \%$ purea in the feed concentrate $\left(T_{3}\right)$ the body weight gain decreased to $0.24 \mathrm{~kg} / \mathrm{h} / \mathrm{d}$ equal to $\mathrm{T}_{0}$. An increase in ADG with the use of purea up to the level of $40 \%$ shows the existence of efficient use of urea through synchronization of carbohydrate fermentation originating from putak with the rate of release of ammonia from urea. The treatment of $T_{2}$ is different from $T_{0}$ and $T_{3}$ but with $T_{1}$ it is not different. ADG between $T_{2}$ and $T_{1}$ is relatively the same because the consumption and digestibility of the two treatments is relatively similar so that the supply of nutrients for the growth is also relatively the same. The research results of Ahmed et al. (2017) concluded that supplementation of slow release urea (Optigen ${ }^{\circledR}$ ) with corn silage was effective in increasing sheep body weight gain. The results of this study are higher than those obtained by Nanda et al. (2014) in Bali cows which were given a supplement of palm kernel cake and palm fronds $(0.30-0.42 \mathrm{~kg} / \mathrm{h} / \mathrm{d})$.

The use of slow release urea as ration supplement also results in an increase in milk production as reported by Xin et al. (2010) occurs an increase in milk production in dairy cows around $2.0 \mathrm{~kg} / \mathrm{h} / \mathrm{d}$. The Body Weight Gain of Bali cattle in this study is still the same as that obtained by Mastika et al. (2000) who provide various supplements to improve body weight gain of Bali cow namely $510-526 \mathrm{~g} / \mathrm{h} / \mathrm{d}$.

The efficiency of feed use is an illustration of how much feed consumed by cows can produce the body weight gain. The use of purea in concentrate feed results in different feed efficiency $(P<0.05)$ in Bali cattle. There is a tendency the increasing levels of purea in concentrate feed, the value of the efficiency of feed use increases. The highest value of the efficiency of feed use achieved by $T_{2}$ followed by $T_{1}, T_{0}$ and $T_{3}$. An increase in feed efficiency will cause a decrease in costs and the efficiency of all production systems become better (Nkrumah et al., 2006). The result of this study is in accordance with Tedeschi et al. (2002) and Kardaya et al. (2018) that the best feed conversion is obtained when growing cows are given slow release urea compared if given conventional urea in natural rations that contain high forage.

\section{CONCLUSION}

The use of purea in concentrate feed as a supplement produces benefits for the productivity of Bali cattle through the increase in growth namely consumption, digestibility, Body Weght Gain, and efficiency of feed use. The results of this study indicate that purea should be used in $40 \%$ concentrate feed in Bali cattle feed, especially if given king grass as its basal feed. Urea can be utilized in Bali cattle feed up to $6 \%$ with the use of purea.

\section{REFERENCES}

1. Ahmed, Z., S.A. Khan, M. Nawaz., A. Shamin., M. Waqas., I. Mohi-Uddin., I. Ahmed, Z.H. Kuthu, and F. Rasool. 2017. Effect of slow release urea supplementation (optigen $®$ ) on the production performance of Kaghari sheep. Adv. Anim. Vet. Sci. 5 (4): 155-159. 
2. Alves, E.M., D.R. Magalhaes., M.A. Freitos., E.J. Santos., M.L.A. Pereira, and M.S. Pedreira. 2014a. Nitrogen metabolism and microbial synthesis in sheep fed diets containing slow release urea to replace the conventional urea. Acta Scientiarum, Animal Sciences 36 (1): 55-62.

3. AOAC (Association of Official Analytical Chemist). 2000. Official methods of analyst, $17^{\text {th }}$ edition, AOAC, Arlington, VA, USA.

4. Bamualim, A. 1991. Penampilan ternak sapi and kerbau sebagai sumber daging di Indonesia. Prosiding Seminar Nasional Sapi Bali, 2-3 september 1991. Fakultas Peternakan, Universitas Hasanudin, Ujung Pandang, Indonesia.

5. Calomeni, G.D., R. Gardinal., B.C. Venturelli, J.E. de Freitas Junior., T.H.A. Vendramini., C.S. Takiya., H.N. de Souza, and F.P. Renno. 2015. Effects of polymer-coated slowrelease urea on performance, ruminal fermentation, and blood metabolites in dairy cows. Revista Brasileira de Zootecnia 44 (9):327-334. http://dx.doi.org/10.1590/S 180692902015000900004.

6. Castaneda-Serrano, R.D., A. Ferriani-Branco., S. Teixeira., T. Garcia-Diaz, and A. DiegoSofiati. 2013. Slow release urea in beef cattle diets: digestibility, microbial synthesis and rumen kinetic. Agrociencia, 47:13-24.

7. Chanjula,P. and W. Ngampongsai. 2008. Effect of supplemental nitrogen from urea on digestibility, rumen fermentation pattern, microbial populations and nitrogen balance in growing goats. Songklanakarin Journal Science Technology 30(5):571.

8. Cui, Z., Q. Meng., W. Ma., X. Zhang., Z. Zhou and L. Ren. 2015. Diversity of the intestinal bacteria of cattle fed on diets with different doses of gelatinized starch-urea. Indian J. Microbiol. 55 (3):269-277.

9. Fattah, S. 1998. The Productivity of Bali Cattle Maintened in Natural Grassland: a Case of Oesu'u, East Nusa Tenggara Province. PhD. Thesis, Universitas Padjadjaran, Bandung.

10. Galo, E., S. Emanuele., C. Sniffen., J. White, and J.R. Knapp. 2003. Effects of a polymercoated urea product on nitrogen metabolism in lactating Holstein dairy cattle. Journal of Dairy Science 86:2154-2162.

11. Gardinal, R., J.R. Gandra., G.D. Calomeni., T.H.A. Vendramini., C.S. Takiya., J.E. de Freitas Junior., H.N. de Souza and F.P. Renno. 2016. Effects of polymer coated slowrelease urea on ruminal fermentation and nutrient total tract digestion of beef steers. $R$. Bras. Zootec. 45 (2):63-70.

12. Geron, L.J.V., S.C. de Aguiar., J.T.H. de Carvalho., G.D. Juffo., A.P. da Silva., E.L. de Souza Neto., K.S.M. Koelho., J. Garcia., L.C. Diniz, and E.J.H. de Paula. 2016. Effect of slow release urea in sheep feed on intake, nutrient digestibility, and ruminal parameters. Semina: Ciencias Agrarias, 37 (4), Suplemento 1: 2793-2806.

13. Golombeski, G. L., K.F. Kalscheur, A.R. Hippen, and D.J. Schingoethe. 2006. Slow release urea and highly fermentable sugars in diets fed to lactating dairy cows. Journal of Dairy Science 89:4395-4403.

14. Goncalves, A. P, C.F.M. do Nascimento., F.A. Ferreira., R. da Costa Gomes., M. de Queiroz Manella.,C.T. Marino., J.J.A. de Abreu Demarch, and P.H.M. Rodrigues. 2015. Slow-release urea in supplement fed to beef steers. Brazilian Archives of Biology and Technology, Vol. 58 (1): 22-30. http://dx.doi.org/10.1590/S1516-8913201502162.

15. Highstreet, A., P.H. Robinson., J. Robinson, and J.G. Garrett. 2010. Response of Holstein cows to replacing urea with a slowly rumen released urea in adiet high in soluble protein . Livestock Science 129:179-185.

16. Inostroza, J. F., R.D. Shaver., V.E. Cabrera, and J.M. Tricarico. 2009. Effect of optigen® on milk yield and composition in commercial Wisconsin dairy herds. Thesis. Department of Dairy Science, University of Wisconsin,Madison, Wisconsin, USA.

17. Jittakot, S. 1999. Effect of cassarea as a protein replacement for soyben meal on feed intake, blood metabolites, ruminal fermentation, digestibility and microbial protein synthesis in dairy cows fed urea-treated rice straw as a roughage. M.Sc. Thesis, Graduate School, Khon Kaen University, Khon Kaen, Thailand. Pp: 171. 
18. Kardaya, D., K.G. Wiryawan., A. Parakkasi, and H.M. Winugroho. 2018. Effects of three slow-release urea inclusions in rice straw-based diets on yearling Bali bulls performance. South Afr. J. Anim. Sci. 48 (4): 751-757.

19. Mastika, IM., IG. L. Oka, IG. N. Bhinawa. 2000. Peningkatan mutu daging sapi Bali melalui paket teknologi pakan konsentrat. Laporan Hasil Penelitian Kerjasama antara Fakultas Peternakan Universitas Udayana dengan Pemerintah Daerah Propinsi Bali. Pp. 1-39.

20. Mastika, IM. 2003. Feeding strategies to improve the production performance and meat quality of Bali cattle (Bos sondaicus). In: Strategies to Improve Bali Cattle in Eastern Indonesia, edited by K. Entwistle and D.R. Lindsay. ACIAR Proceedings No. 110. 4-7 February 2003, Bali, Indonesia. Australian Centre for International Agricultural Research, Canberra.

21. Mentz, A.M., W.A. Van Niekerk., A. Hasten., R.J. Coertze and B.S. Gemeda. 2015. Effect of diets differing in rumen soluble nitrogen on utilization of poor-quality roughage by sheep. S. Afr. J. Anim. Sci. 45 (5):528-537.

22. Nanda, D. D., A. Purnomoadi and L.K. Nuswantara. 2014. Penampilan produksi sapi Bali yang diberi pakan dengan berbagai level bungkil and pelepah sawit. Agromedia. Vol. 32:54-63.

23. Nkrumah, J. D., E.K. Okine., G.W. Mathison., K. Schmid., C. Li., J.A. Basarah., M.A. Price., E. Wang, and S.S. Moore. 2006. Relationship of feedlot feed efficiency, performance and feeding behaviour with metabolic rate, methane production and energy partitioning in beef cattle. Journal Animal Science 84 (1):145-163.

24. NRC (National Research Council). 2000. Nutrient Requirements of beef cattle $7^{\text {th }}$ rev. Ed. National Academy Press, Washington, D.C., 2000. 242 p.

25. Paengkoum, P. and K. Bunnakit. 2009. Replacement of soybean meal with cassava pulp mixed with urea gelatinizes (Caspurea) in concentrate diets of beef cattle. Agricultural Journal 4 (5):242-249.

26. Rodriques A.A. 2003. Utilizaḉao de nitrogẻnio nảo-protẻico em dietas de ruminantes. In: Simpỏsio Golano sobre manejo e nutriçaâo de bovinos de corte e leite:Proceedings: Golânia:CBNA.

27. SAS 2008. User's Guide: Statistics. Version 9.1. Ed. SAS Institute, Cary, New York.

28. Siciliano- Jones, J. and J. Downer. 2005. Utility and safety of slow-release nitrogen product: optigen ${ }^{\circledR}$ 1200. In: Nutritional Biotechnology in the Feed and Food Industries. Proceedings of Allteck's $21^{\text {st }}$ Animal Symposium. Lyons T P and Jacques K A, ed. Alltech UK, Lexington, KY, USA.

29. Sinclair, L.A., C.W. Blake., P. Griffinand G.H. Jones. 2011. The partial replacement of soybean meal and rapeseed meal with feed grade urea or a slow-release urea and its effect on the performance, metabolism and digestibility in dairy cows. Animal 6 (6):920927. Doi:10.1017/S1751731111002485.

30. Tedeschi, L.O., M.J. Baker., D.J. Ketchen, and D.G. Fox. 2002. Performance of growing and finishing cattle supplemented with a slow-release urea product and urea. Canadian Journal of Animal Science, 82: 567-573.

31. Wanapat, M. 2000. Rumen manipulation to increase the efficient use of local feed resources and productivity of ruminants in the tropics. Asian-Australasian Journal Animal Science 1 (Suppl):59-67.

32. Wirdahayati, R.B. and A. Bamualim. 1990. Penampilan produksi and struktur populasi ternak sapi Bali di pulau Timor, Nusa Tenggara Timur. G.N.R. Haryana, A.A.B. Palguna, I.B. Djagra, K.B.G.N. Saka, I.B. Mantra, M. Mastika and D.K.H. Putra (ed.). Seminar Nasional, Sapi Bali. Proceeding Seminar Nasional Sapi Bali, 20-22 September 1990. Fakultas Peternakan, Universitas Udayana, Denpasar, Bali, C1-C5.

33. Xin, H. S., D.M. Schaefer., Q.P. Liu., D.E. Axe, and Q.X. Meng. 2010. Effects of polyurethane coated urea supplement on in vitro ruminal fermentation, ammonia release dynamics and lactating performance of Holstein dairy cows fed a steam-flaked cornbased diet. Asian-Australasian Journal Animal Science. Vol. 23 (4): 491-500. 